\title{
The Developing Trend of Independent Designer Brands and Brand Managing Company in China
}

\author{
Yiyao Zhu \\ School of Management, Jinan University, Guangzhou, China \\ Email: zhuyiyao1992@qq.com
}

Received 12 October 2015; accepted 9 November 2015; published 12 November 2015

Copyright (C) 2015 by author and Scientific Research Publishing Inc.

This work is licensed under the Creative Commons Attribution International License (CC BY). http://creativecommons.org/licenses/by/4.0/

(c) (i) Open Access

\begin{abstract}
Recent years, more and more independent designer brands have stepped into public's awareness, becoming a newly emerging force of online apparel sales. In this context, brand managing company and corresponding electronic business platform only for independent designer brands emerge gradually as the time requires. Brand managing company means a company who possesses or cooperates with many independent designer brands. Some of these brand managing companies are originated from traditional fashion apparel company. The objective of this research is to describe and explain the developing trend of the apparel industry, brand managing company and independent designers in China. And the outline is also according to these three parts.
\end{abstract}

\section{Keywords}

Independent Designer Brand, Online Platform, 020, Apparel Industry, Brand Managing Company, Developing Trend

\section{The Developing Trend of Chinese Apparel}

Chinese apparel industry is undergoing transformation, so as many other Chinese traditional manufacturing business, rather than "made in China", "Designing in China" is becoming the developing trend. That's why the companies who possess the original designing resources have a great potential for growth. Customers' consumption habit is changing, independent designer brands and customizing products will surely be accepted by more and more people, which is really a big chance for "made in China".

Unlike the professional designers of the famous brands, independent designers always possess their own brands [1]. Therefore the independent designer brand means the private brand established by the independent designers with their own resources, the products of independent designer brand always present some distinctive 
features or personality elements.

So far, Chinese fashion industry is still not mature enough, the supply chain is also not complete. According to the records, $95 \%$ of the high-end apparel marketing is under charge of foreign brands. Compared to foreign markets, domestic fashion buyer shopping mall just began to develop in China mainland. Even though some fashion buyer company has a transient flourish but they have not yet formed a virtuous circle because of high cost, closed supply chain and channel lacking. In addition, domestic design industry has many new designers but lack of brand management and brand awareness.

On the other hand, according to the China fashion index of 2012, official data show that $42.5 \%$ of people who can afford luxury have interests in independent designer brands. Besides, among those who have ever purchased domestic design brands, $97 \%$ of them own international luxury commodities meanwhile, which demonstrates independent designer brands' attraction to high-consumption crowd.

Nowadays independent designer brands are developing at a high speed both online and offline. Time of personalized consumption is coming, and it's an opportunity for independent designer brands [2]. Gradually consumers will have a better understanding of added value of designing, more and more people will have a better interest in independent designing products and customizing products [3]. Moreover, with the increasing development of internet and technology, e-business platform will be the main marketing channel for apparel industry. Through the mature payment platform, exhibition platform and admin platform, customers can get a more convenient service while designers can get better revenue with a lower cost. However, offline experience store is still and always a vital part of brand marketing. Because experience is always important in the buying decision; according to the survey most customers are used to purchasing after seeing and feeling [4]. Experience will endow the present products and services with new value, the combination of online and offline marketing will bring apparel industry a new and huge benefits increase.

\section{The Developing Trend of Independent Designers Brand}

Most of the foreign designer brands are established through a long-term development and cultivation. For instance, Armani, established by famous European fashion designer George Armani, is also a independent designer brand. The foreign apparel industry culture has a better revere and honor to original innovative designers. And people in western countries are more acceptable to independent design brand. That's why almost all the famous independent designer brands are from western countries.

Not only in Europe, There are also many excellent designers in Japan, but only less than 20 of them are outstanding oversea because most Japanese designers are at service in their domestic fashion industry, which guarantee a flourish of Japanese fashion industry.

Besides, international fashion buyer, which is similar to fashion brand managing company, has been a profession oversea for about fifty years, nowadays buyer culture is still developing rapidly. We can say that buyers are the bridge of brand and market, designers and customers. They are becoming a force to promote foreign fashion industry to large-scale production. On the other hand, the flourish of buyer culture will also develop the society's acceptance of independent designer brands.

Actually in China There are some fashion companies paying more and more attention to independent designer brands. Apparently cooperating with a mature fashion company is also a better choice for new designers, because new designers will be offered enough space to put their ability \& value in good use, also, company will take care of all the stuff from package to promotion like a full-service broker [5]. The services include: Firstly, Production. Company will help designers contact fabric supplier and factory to ensure the normal operation of upstream supply chain and to set designers free from high cost; Secondly, Sale channel. Some companies will offer normal and mature platforms as sales channel, prevent designers from a mass sales condition and copyright disputes [6]. Besides, company may search for cooperating chance with high-end brands and luxury brands; Thirdly, package \& promotion. Company will give extra promotion opportunities for outstanding brands on the platform; Lastly, Other cooperating chances. The online platform and BBS inside the company make the interflow and communication possible among independent designers, which will give them a chance to cooperate with each other.

\section{Brand Managing Company in China}

In 2013 a fashion apparel company named Mindu in Guangzhou created the first platform, Sifang Street, which 
was only for independent designers. Helping new designers achieve designing dream is the mission of this company. On the other hand, providing new and diversified shopping experience for customers is the goal of this company. The business model of Mindu is as shown in Figure 1, which is similar to other brand managing companies.

For designers, there are several different kinds of cooperation patterns between independent designers and brand managing company, profit sharing ratio is set up differently according to different cooperation methods [7]. There are mainly three kinds of Cooperation patterns:

Firstly, designers provide the designing plan, company take the responsibility of producing and marketing [8]. Which means designers only need to provide designing draft, company will do the rest things including manufacturing, marketing and after-sales services.

Secondly, Designers and their studio provide mature product samples, company pick out potential samples and help designers to launch the products and promote their products and ideas to the market.

Thirdly, Designers provide product samples, on which basis consumers can customize the personalized products according to their own demand, afterwards designers will help customers modify and improve the customized products [9]. Producing and marketing is in the charge of designers' studio or company. In this way customers' diversified demands can be met and satisfied.

For customers, the target market of this kind of independent brand company is the personalized, fashionable and young customers. Take Mindu as an example, it not only has a mature online platform (Sifang Street) to provide a better shopping experience for customers, but also set up some offline experience stores to provide an one-stop service including experiencing, guiding, booking and customizing, meanwhile deliver the designing idea and corporation culture [10]. There are mainly three kinds of platform service patterns:

Firstly, customizing service. Sifang Street has a special module for customization. Customers can choose designers, colors and slogan. Therefore the final products will both carry the fashion idea of designers and the characters of individual customers [11].

Secondly, point-to-point service. Which Includes not only the one-to-one services from pre-sales to after-sales, but also the communication between the designers and their customers. The BBS makes that contact possible, which also increases the satisfaction and even loyalty of customers.

Thirdly, personalized service from offline experience store. There are many professional shopping guides at store who can introduce and pick apparel for customers, customers may have a more authentic and concrete experience in the offline stores before purchasing things online. Besides each store will have a professional individual figure designing team to offering customizing service, the team would include designers, fashion coordinators and even fashion stars. In the future there will be fashion salon or party for designers and VIP members among customers.

For company, they will explore and recruit both famous and new independent designers, because for fashion

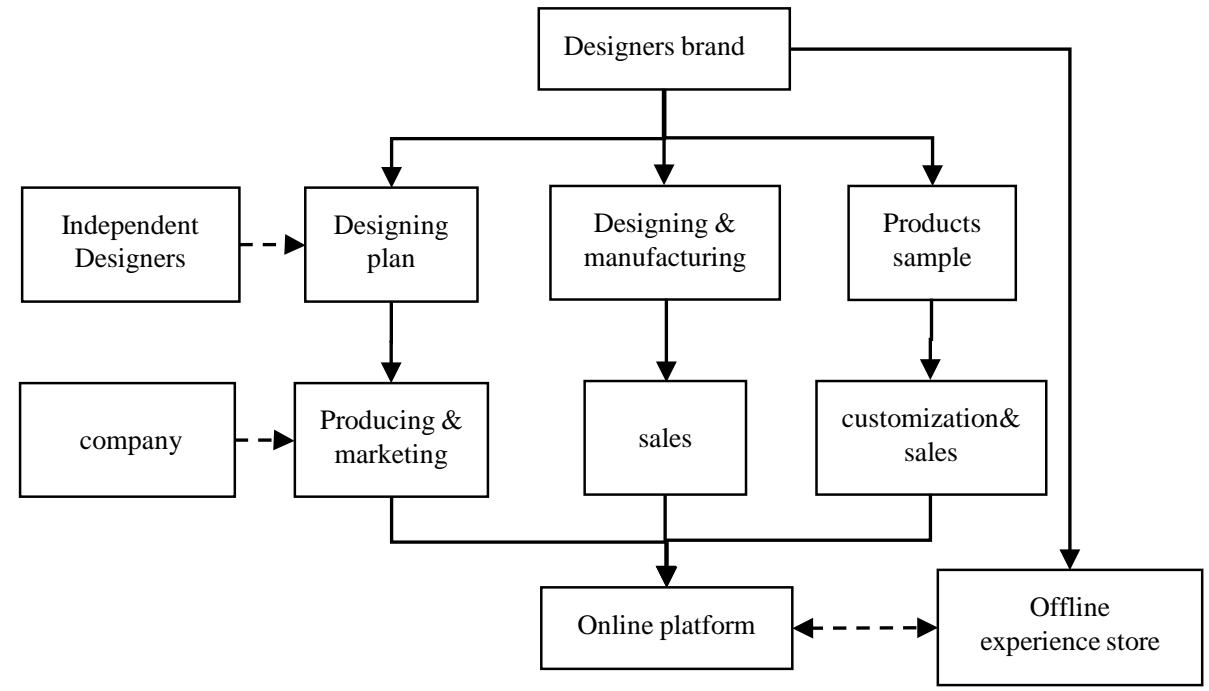

Figure 1. Business model of the independent designers brand managing company. 
buyer company or brand managing company, outstanding designers are always the most significant capital. Usually company have four ways to dig new designers: Firstly, explore young designers in designing colleges; Secondly, pick out not so famous but potential designers in fashion weeks; Thirdly, Select new designers through every kinds of designing competition both in mainland and HK, Macau; Lastly, Cultivate company's own designers.

\section{Conclusions}

According to the analysis above, original independent designing brands have a developing trend as follows:

Firstly, time of individual purchasing is around the corner, domestic original design brands will embrace a massive-scale development. Customers are beginning to realize the attached value of original design. The original design brands will meet with a large-scale development especially across the coastal cities, and next generation will be much more patient and confident to original independent designer brands.

Secondly, designer brands managing companies offer lots of opportunities for young designers. The designer management company will offer more chances to more new designers.

For newly-entrants designers, brand managing company helps to outsource the marketing, HR and finance module so that they can concentrate on designing.

Thirdly, combination of traditional commerce and mobile e-commerce platform (O2O) will be a main sales model of Chinese apparel industry [12]. Cooperation can help independent designers make a good use of e-commerce platform including network infrastructure, payment platform, safety platform, management platform and many other functions to do its commerce activities effectively and efficiently. Moreover, with the development of science \& technology, traditional internet has been through a change towards mobile internet. In the recent days, mobile terminal becomes another significant way for business.

Lastly, offline experience stores will be a necessary part of brand management [13]. With the development of service industry, offline experience stores will be absolutely the backbone of industry development. Experience will endow present products with new value, which can become a new selling point. Setting experience store, establishing the $\mathrm{O} 2 \mathrm{O}$ sales model will give customers a better understanding and access of the brand.

\section{References}

[1] Tien, J.M., Krishnamurthy, A. and Yasar, A. (2004) Towards Real-Time Customized Management of Supply and Demand Chains. Journal of Systems Science and Systems Engineering, 13, 257-278.

[2] Kumar, A. (2007) From Mass Customization to Mass Personalization: A Strategic Transformation. International Journal of Flexible Manufacturing Systems, 19, 533-547.

[3] Matzler, K., Waiguny, M. and Fuller, J. (2007) Spoiled for Choice: Consumer Confusion in Internet-Based Mass Customization. Innovative Marketing, 3, 7-18.

[4] Oppewal, H., Tojib, D.R. and Louvieris, P. (2012) Experimental Analysis of Consumer Channel-Mix Use. Journal of Business Research, 66, 2226-2233.

[5] Lin, C. and Nguyen, C. (2011) Exploring e-Payment Adoption in Vietnan and Taiwan. The Journal of Computer Information Systems, 51, 41-52.

[6] Zhu, K. (2004) Information Transparency of Business-to-Business Electronic Markets: A Game-Theoretic Analysis. Management Science, 50, 670-685. http://dx.doi.org/10.1287/mnsc.1040.0226

[7] Tien, J.M. and Berg, D. (2003) A Case for Service Systems Engineering. Journal of Systems Science and Systems Engineering, 12, 13-38.

[8] Chintagunta, P.K., Chu, J. and Cebollada, J. (2012) Quantifying Transaction Costs in Online/Off-line Grocery Channel Choice. Marketing Science, 31, 96-114.

[9] Zo, H. and Ramamurthy, K. (2009) Consumer Selection of E-Commerce Websites in a B2C Environment: A Discrete Decision Choice Model. IEEE Transactions on Systems, Man and Cybernetics, Part A: Systems and Humans, 39, 819839.

[10] Anand, K.S., Pac, M.F. and Veeraraghavan, S. (2011) Quality-Speed Conundrum: Trade-Offs in Customer-Intensive Services. Management Science, 57, 40-56. http://dx.doi.org/10.1287/mnsc.1100.1250

[11] Eyers, D. and Dotchev, K. (2010) Technology Review for Mass Customisation Using Rapid Manufacturing. Assembly Automation, 30, 39-46. http://dx.doi.org/10.1108/01445151011016055 
[12] Subramanian, N., Gunasekaran, A., Yu, J., Cheng, J. and Ning, K. (2013) Customer Satisfaction and Competitiveness in the Chinese E-Retailing: Structural Equation Modeling (SEM) Approach to Identify the Role of Quality Factors. Expert Systems with Applications, 41, 69-80.

[13] Chocarro, R., Cortiñas, M. and Villanueva, M.-L. (2013) Situational Variables in Online versus Offline Channel Choice. Electronic Commerce Research and Applications, 12, 347-361. http://dx.doi.org/10.1016/j.elerap.2013.03.004 